\title{
Manufacturing Racial Humor ${ }^{1}$
}

\author{
Luis Silva-Villar \\ Mesa State College \\ lsilvav@mesastate.edu
}

\begin{abstract}
The study of the scathing content of “¿Cómo se dice X en (language) Y?" jokes is compared to the cultural use of American Mock Spanish: i.e: "no problemo" expressions. Our study analyzes the collected corpora of Cómo se dice... jokes and organizes them by regional areas and content variation. If Mock Spanish relies on the apparent social weakness of Latinos in the US, Cómo se dice... jokes revile stereotypical characters and cultures recognized as inferior by Spanish-speaking joketellers. Our surprising conclusion is not that the telling of these jokes is bluntly reprehensible but that, with cruel accuracy, the laugh they produce helps us humans know the place we occupy in a predefined scale of stereotypical cultural bias.
\end{abstract}

\section{Introduction: the spark of humor fulminates}

No culture is without jokes. Or humor for that matter ${ }^{2}$. Although jokes abound, theories about the nature of humor are few and often contradict each other. But without doubt, when one hears, “wanna hear a joke?" we all have approximately the same expectations, especially when we recognize the type of joke. The jokes that we are going to focus on here can be summarized as a short story with a linguistic foundation. Our jokes are tricky due to their manner of execution since they leave the listener (or reader) searching for an impossible resolution: it is known that the intended answer will never be the humorous one; and we know it because without an ingenious modification, the answer will not inspire laughter. The need to find out the hidden answer, on the other hand, makes a contribution to the ludic experience, which is satisfied when the joke is good and meets expectations. In essence, jokes resemble literature: as poetry 
lacking artistic intentions (Bousoño 1970[1952]). Another characteristic of our special jokes is that their authors are for the most part anonymous, but interestingly, an original joke can come to have a hefty monetary price.

The jokes we are focusing on are founded in racism. Interestingly, everybody laughs at racial jokes whether or not they are racist themselves, which leaves us wondering how much joking a person can handle before feeling uncomfortable. At the core of this study lies the acceptance of this understanding and a way to take advantage of our findings to turn these sentiments to our benefit. The thinning of cultural barriers, present and future, will depend heavily on this acknowledgement.

\section{The study ${ }^{3}$. Cómo se dice jokes}

Data were collected from two different sources: a genre of jokes in the Hispanic world referred to as Cómo se dice jokes and an American way to generate pseudo Spanish, which has been technically identified as Mock Spanish.

Jokes have been selected by their linguistic relevance. They follow the pattern of ¿Cómo se dice $X$ en la lengua $Y$ ? 'How do you say $\mathrm{X}$ in language Y?' A level of familiarity with the stereotypical sounds, or other stereotypical linguistic traits of the target language (in the joke) is a prerequisite to produce and/or interpret the joke. Some level of contact with the target group is also assumed. Thus, the stereotype is born either from the direct experience or through exposure to materials representing the target group such as movies and/or other forms of media.

The advantage of combining linguistic knowledge and jokes is illustrated by the following fact: if in Mexico there are tons of jokes about the stereotypical character of the (pseudo) Gallego, lit. people from Galicia (Spain) [which can be equated to a "blonde joke" in English], we have no doubt that they cannot truly refer to actual people from Galicia. It is enough to consider its linguistic traits to prove it. In contrast, knowledge of language is indispensable in creating or enjoying Cómo se dice jokes.

Our study allows the researcher to take advantage of linguistic characteristics of the jokes - those under scrutiny in our investigation - and apply them as an innovative formal tool for sociolinguistic and anthropological research. Our study allows investigators to penetrate the meaning of the jokes by offering an additional input with which to get linguistic substance, which in the case of the chistes de gallegos helps to prove that the Gallego jokes previously mentioned are not about real people from Galicia.

The Cómo se dice jokes have a hallmark: whatever is said about one cultural group, upon its stereotypes, is not applicable to a different ethnolinguistic group indiscriminately. Only bad joke tellers do so. Thus stereotypical Gallego jokes, as opposed to what happens in Cómo se dice jokes, may be applied to any individual playing the role of tonto del chiste 'a dumb character'. As expected, this particular type of Gallego jokes are found in a variety of cultures - they abound, in fact-, and it is not unusual to find the exact same joke in different cultural/ethnic groups. Essentially they illustrate attempts to reinforce identity at the cost of the denial of some minority group. 
In France these jokes have the Belgians as the target group; in the US, the Polish; in Denmark, the Scottish (Davies, 1982).

Not surprisingly, our corpus of Cómo se dice jokes does not contain examples of Cómo se dice $X$ 'en gallego' confirming the impossible association of Gallego with truly Galician-speaking people, whose language traits are inaccessible to joke teller ${ }^{4}$.

Once the accessibility notion is established the Cómo se dice jokes emerge as an irreplaceable access to stereotypical aspects of culture. The corpus of collected jokes speaks for itself. Over 1363 jokes from 12 online documents have been collected, with some additions conveniently listed in the bibliography. Some have been taken from spontaneous colloquial speech, and some come from Spanish television in the US. The most recent one comes from the popular TV figure Don Francisco. Here it is: ¿Cómo se dice tatuaje en chino? (Univision, April 2007)

From a descriptive point of view, the vast majority of Cómo se dice jokes fit into one of three groups identified here as "African”, "Japanese-Chinese” (which we refer to by the joint term "Asian"), and "Arabic" (see Appendix I). Far from them and in significantly lower numbers, and different taste, are "Russian", "German", "Portuguese", "French", and a few others.

Interestingly, and surprising to our study, we have noticed the scarcity of ¿Cómo se dice $X$ en inglés ['in English'] jokes and —in those few cases found - that the content is unusually respectful, considering of course the derogatory characteristics of the genre. Only 25 jokes of ¿Cómo se dice $X$ en ingles? are cataloged in our study, of which several are duplicated (some on multiple occasions) and others only imply English (see Appendix II).

Upon making a typology of the Cómo se dice genre, we find three possible strategies adopted by the teller, which were identified with a label: (i) those that are based on sound properties [¿Cómo se dice en chino tatuaje? -Tan Man Tsao, lit. 'youhave-been stained'] labeled as phonomimetics; (ii) those based on the word form: [¿Cómo se dice en escandinavo calzoncillo? -Escondenabos] or morphomimetics, and (iii) those based on cultural stereotypes or socioreflexives [¿Cómo se dice en inglés 'tu suegra no viene a cenar esta noche'? - Yeaaah!/Hurrah!]. But without doubt the structures giving this genre its originality, and success, combine the first two: [¿Cómo se dice diarrea en japonés? -Kagasawa (approximately, 'to have a watery excrement')]. Proper nouns, names of cities, movie titles or prominent movie star names make up the source of inspiration for the joke teller mostly. Other characteristics are at the mercy of the joke teller's own personal experience.

\section{No speako el spanisho: Mock Spanish}

It has come to be called mock Spanish within the Anglo society (as well as in Spanish), a type of English with Spanish flavor added. The mock in the label comes from the imitative and deceitful character of this funny (?) variety of language, which little by little spreads more and more across the US. To clarify its particular meaning we depart from a familiar American bird: the mockingbird. 
Mockingbirds owe their name to their unique ability to imitate the song of any other bird which enters the mockingbird's territory. Spanish borrows from nahuatl the name of this bird, a name that advertizes its mimophonic skills. Its name in Spanish, sinsonte, is nothing but a Spanish accommodation of the nahuatl word centzontlatolle which means 'bird of 400 languages'. This denomination suggests that it can imitate a large number of bird calls. Its scientific name aids with understanding its reputation: mimus polyglottos 'multi-imitator of languages' or 'polyglottal imitator'.

Two components characterize both the mockingbird and Mock Spanish: imitation or mimicry and deceptive intentions.

Mock Spanish has been broken down into subclasses, some of which have minor value for this study. The relevant one here is the 'o-ization', or addition of a paragogic 'o' to all major grammatical categories ${ }^{5}$. 'O-ization' is typically used as a magic wand to make the 'o-izer' feel superior to the members of the mocked group. In this case, Hispanics in the US.

The morphological component of the '-o', is very systematic (linguistically speaking) which justifies its choice in our investigation. Some examples are: cheap-o, no problem-o, speak-o, jok-o, professor-o. Other possibilities, ignored here, are asystematic and less interesting to develop a linguistic tool to study human societies ${ }^{4}$. The 'o-ization' introduces a degree of depreciation by appending a sound to the word, which confers the 'o' a magic value: a quasi-superstitious mode of hurting others' feelings through language. To comprehend the extent of its power let us take the adjective: cheap. This adjective has a regular comparative: cheaper, whose form itself does not add any cultural devaluation. If we consider now the interpretation of the ' $\mathrm{o}$ ized' form of cheap, which is cheap-o, we observe that, quite differently, the 'o-ization' provokes an automatic marginalizing effect: a type of downgrading associated with negative Latino stereotypes. This derogatory-linguistic activity must be understood as a disgrace, a consequence of users' abrogation of abusive cultural superiority. The 'oizing' effect is intriguing and should be carefully studied since it arouses easy laughter from everybody, which often includes, of course, Latinos themselves.

\section{A Theory of Cultural Relativity}

Directionality becomes important as we progress in our research. The Cómo se dice jokes and the Mock Spanish cannot apply reciprocally between the relevant human groups. What hides an apparent and clean fun joke oftentimes is the reaffirmation of a privileged class over an emigrant or minority group. There are two pieces of evidence reinforcing our view; on one hand, the aforementioned dearth of Cómo se dice en inglés... jokes; and on the other, the difficulty of creating reverse Mock Spanish. The relation between unequal social groups makes the establishment of any cultural balance impossible. One imaginative way to circumvent this drawback has been to develop Mock-Mock Spanish, which is nothing more than adopting the personality of the 'o-izer' and exaggerating the mocking to a point where the 'o-ization' become extremely ridiculous. The Cómo se dice jokes on the other hand, do not have a short-term cure 
(from the Latino perspective) since Latinos are the ones who abrogate the condition of superiority upon themselves. Kenneth Pike (1945) pioneered the identification of the strict directionality of mocking uses of language. In one study of Mixteco language and culture he observed that the Mixteco speakers reacted to mispronounced Mixteco words of outsiders, generally Spaniards, by following their requests literally despite knowing the intended meaning. Later Jane Hill would demonstrate the marked supra/infraposition to which all ethnic groups can be subject to. Latinos (Spanish speakers) in the US play that role with respect to the Anglo dominant group according to Hill (2003).

One can propose a universal scale of stereotypes to which we all ascribe, in which we always end up above or below other cultural groups. The higher we place ourselves, the more groups are relegated to cultural inferiority. An essential question here is "do we decide where on the scale we are or do others?" A good answer is implicit in a Spanish proverb: No hiere quien quiere sino quien puede (approx. 'One cannot offend who he wants, but who he can'). This understanding rationalizes the absence of reverseMock Spanish, explaining simultaneously the parallel development of Mock-Mock Spanish, and covering an explanation of the absence of Cómo se dice en inglés... jokes (or their mild/naive content) [see examples in Appendix II].

\section{An unequal balance}

The fixation of a hypothetical scale with cultural appreciation as the cultural variable distributing nations and human groups along it, expects to situate each group on a stereotypical level. That level is a function of the relative cultural interaction of that group with the rest of the groups it shares a social (or geographical) area with. Each group will put in order below itself those groups viewed (consciously or unconsciously) as inferior, which reveals the instinct of downgrading. On top of them, they will place those acknowledged (consciously or unconsciously) as superior (Arguedas, 1996). The jokes in our investigation neatly separate the groups not recognized as equal, either from above and/or from below.

The data obtained from Cómo se dice jokes make explicit the cultures Latinos put beneath themselves: Africans, Asians (including Japanese and Chinese) and Arabs. Above themselves, American Anglos —which occasionally appear hidden under English- occupy the upper part of the scale.

The absence of Cómo se dice en francés [in French] jokes probably is in keeping with the decline of Francophone culture in the Hispanic world. Not long ago there were a 'faltaría plus', 'echar a la rue' or, typical of the comic duo Tip y Coll, a 'gilipolluá', “por ejemplón”, “le vasé” or a "no nos cabrón” instead of 'no nos cabría'.

The absence of Cómo se dice en español (de/en España)... [from/in Spain] is also notable and worth studying. The only registered case in our corpus was collected in Spain and was produced by a Spaniard: ¿Cómo dice un español eyaculación precoz? Te juro que es la primera vez que me pasa 'How would Spaniards say (in Spanish) premature ejaculation? - I swear this is the first time this has happened to me'. If one compares this joke with the joke's Chinese counterpart: Mm Ya-ta 'Mm All Done!', 
both jokes inspire laughter but only the Mocking Chinese which is reinforced by the tonal fake intonation of the joke teller results in blatant racism. This contrast supports the need of splitting racial awareness and self-criticism.

A cruel thought would be that we all laugh at racial jokes because they let us feel a sense of relief (Freud, 1967). If we were given the power to do so, somebody would be tempted to ban both the public recitation of racial jokes and the 'o-izing' jargon. It appears convenient to postpone this ban, though, because the laughing is real and those who laugh at racial jokes surely cannot be classified as inveterate racists. Could it be said that humans are capable of dissociating racial attitudes from having fun? Should we just go with the flow and spend our time doing something else? Let's try an imaginative approach.

\section{A fair and just closing}

A visit to a psychologist would convince anyone of the benefits of laughing. The linguistic ability that good joke makers should display is also significant. Not everybody has the skills to create these jokes. In many cases it demonstrates the linguistic sensibility of the speaker. 'O-izing' is proportionally easier, although some speakers also do it more gracefully than others.

In an attempt to avoid ending the article depressed about our unconscious acceptance of racial humor, we are going to try a practical use of the aforementioned cultural scale. We maintain that the cultural scale is a movable evaluating index able to accurately represent our level of sensitivity to racism. Also, about how much we have to work to improve (and modify) our perception of racial attitudes. Even we claim that it could also be a good source of information on the availability (or not) of Mock-Mock Spanish $^{6}$ (Silva-Villar, 2006).

The final goal — which we should be committed to - would be to gradually narrow down the distances along the cultural scale.

Our study demonstrates that we construct a substantial part of our cultural boundaries with our crude "humorous" attitudes. If we can laugh at ethnic jokes it is because we accept the inequality of cultural relations. Therefore these cultural "boundaries" are much less visual than "virtual".

By way of rounding off: Some humans know how to laugh at their own miseries better than others. An African-American, for example, hears a joke about blacks with more complicity than a white hears one about his/her own racial group. And surprisingly, some whites are too worried and get more offended about black jokes than the blacks themselves (Middleton, 1959). In this investigation, the higher on the cultural scale one is, the harder it is for him/her to absorb the impact of the joke. The ability to laugh at our own idiosyncratic weaknesses is therapeutic and should be taught in general education as a way to develop awareness about the complexity of facing racial humor. Accepting some kind of truth in that, some cultural groups have quite a head start. The following joke is a fine example of humoristic Jewish self-criticism: 
A young Jewish man auditions for a job as a radio announcer. When a friend asks if he got the job, he shakes his head sadly. "Why did they turn you down?" the friend asks and he replies, "S-s-s-same old th-th-th-thing. P-p-p-rejudice" (Levine 325; 492 n. 18).

\section{Notes}

1. I thank the audience of The 11th International Conference "The Border: A New Cultural Concept", May 2, 3, 4, 2007, where a preliminary version of this article was presented, and an anonymous reviewer for his/her comments. I also thank Cheryl Olson and Sean Silva for editing comments.

2. The bibliography contains significant information about the theory of humor in Spanish tradition.

3. Most of the investigation has covered 12 web pages of which half of them lack Cómo se dice en inglés... jokes, in the other half the (Cómo se dice en inglés...) jokes were repeated and cut-and-pasted $50 \%$ of the time, sometimes with English not explicitly mentioned. Apart from there being a certain degree of uncertainty regarding the authors of jokes, on some web pages the name of the person who submitted the joke is posted. After eliminating ageneric names it can be concluded that the number of jokes submitted by males exceeds minimally the amount sent in by females, which was not predictable at the start of the investigation due to the frequent misogynistic character of the jokes. The total count of jokes that refer to English, including even the repeated ones and those that do not even say the word 'English', does not reach 2\% (in the pages in which they appear). The majority of the jokes, divided into three groups: 'African'. 'Japanese-Chinese', 'Arabic' (see Appendixes), never go below 60-70\% of the total. The source of the jokes is also important because, as it has been said before, contact and familiarity are required. Because of that, jokes mocking the native language Cachiquel will only appear in Mexico; jokes mocking Guaraní, only in Argentina or surrounding countries.

4. The existing Galician jokes noted in our investigation are blatant copies of Portuguese: ¿Cómo se dice en gallego preservativo? - Chubasqueiro do pito/ [¿...] supositorio? - Chupachús do culeiro.

5. One small sample: (i) Purely accidental: Fleas Navidad, hasta la saña, muchas grassyass, (ii) phonotactical: “caRRRRne asada like Ricardo Montalban (as the Mexican actor pronounces it) [Taco Bell commercial], and (iii) third-world negative stereotypes: to call a ridiculous presidential candidate el presidente (Ross Perot) or the use of "offensive words" such as cojones without any embarrassment (Madeleine Albright in a discourse in the UN criticizing Fidel Castro) [Silva-Villar, 2006].

6. A good example of Mock-Mock Spanish is the following commercial ringtone set in a generic southern border town. It starts with a patrol siren, after which an official speaking with a normal southern accent says: "Cálmate, cálmate, this is la migra. Por favor, put the oranges down and step away from the cell phone. I repeat-o, put the oranges down and step away from the telephone-o. I'm deporting you back home-o" (Silva-Villar, 2006).

\section{References}

Arguedas Cortés, Gilda Rosa (1996): “Análisis lingüístico de chistes del tipo “¿Cómo se dice 99 en chino? Filología y Lingüística XXII(1): 129-140. 
Bousoño, Carlos (1970[1952]): Teoría de la expresión poética. 2 vols. Biblioteca Románica Hispánica. Madrid: Editorial Gredos.

Casares, Julio (1961): "El humorismo" in El humorismo y otros ensayos. Madrid: EspasaCalpe, 21-48.

Davies, Christie (1982): "Ethnic Jokes, Moral Values and SOCAL Boundaries”. The British Journal of Sociology Vol. 33, No.3: 383-403.

Fernández Flórez, Wenceslao (1945): El humor en la literatura española. Induction speech to the RAE, May 14, 1945. Madrid: Imprenta Sáez, 1-29.

Freud, Sigmund, (1967), El chiste y su relación con lo inconsciente, in Obras Completas, vol. I. Madrid: Biblioteca Nueva, pp. 825-937.

Hill, Jane H. (1995): "Mock Spanish: A Site For The Indexical Reproduction Of Racism In American English”. Language \& Culture: Symposium 2. Available: [http://languageculture.binghamton.edu/symposia/2/part1/index.html]. . (1999): "Language, Race, and White Public Space”. American Anthropologist 100(3): 680-689.

(2003): “Mocking Spanish from above and below”.Mary Ruth Wise, Thomas N. Headland \& Ruth M. Brend, eds., Language and Life: essays in memory of Kenneth L. Pike. Dallas: SIL International and University of Texas at Arlington Publications in Linguistics, 139, 107-118.

Leveen, Lois (1996): “Only When I Laugh: Textual Dynamics of Ethnic Humor”. MELUS vol. 21, No. 4, Ethnic Humor (Winter, 1996): 29-55.

Middleton, Russell (1959): “Negro and White Reactions to Racial Humor”. Sociometry vol. 22, No. 2: 175-183.

Silva Villar, Luis (2003): “Schwarzenegger: ‘No problemo””. La Opinión, July 20, 2003. Los Angeles.

. (2005): “Mock Spanish: 'No speako the Spanisho'”. La Opinión, March 27, 2005. Los Angeles. Angeles.

\section{Online References to Cómo se dice jokes.}

Atriunfar.net: www.atriunfar.net/humor/comosedice.html

Chistes: http://bebop.com.ar/humor/cuentos22.html (argentinos)

Chistes de cómo-SE-DICE: www.publispain.com/chistes/chistes-de-como-se-dice.htm

Humor. Comunidad Astalaweb www.humor.astaleweb.com/C\%C3\%B3mo\%20se\%20dice/C

Iespaña: www.iespaña.es/israevil/Chistes/Como.html?

http://lsantos2000.tripod.com/humor/humor3.htm

Lo peor.com: http://chistes.lopeor.com/chistes/imostrar.asp?icat=26\&isize=18

Muydivertido.com: www.loschistes.com/shjokes.php?id=Buscar\&sel_clasif+tcla\&s

Paisdelocos: www.paisdelocos.com/chistes/categorias/como_se_dice/

Planetachistes.com: http://www.planetachistes.com/jokes_category.php?cat_id=79

Todochistes.net: www.todochistes.net/chistes-pagina-24-10.html

Spanish Language Resources: www.spanishinperu.org/spanish-language/jokes/index.asp?size

StarMedia: http://humor.orange.es/chistes/chistes/categorias/como_se_dice 


\section{Appendix A.}

Joke collection. ¿Cómo se dice X en africano, chino, japonés,...?

Racial rating: $\mathrm{X}=$ blatant, $\mathrm{Y}=$ mild.

Africano (Zulú, Mandinga, Suahili, Batusi, aborigen...):

- $\mathrm{X}=$ tienes olor a chivo/ (creo que) estoy embarazada/ hacer el amor/ follar/ esposa/ afortunado en el juego, mala suerte en el amor/ mujer embarazada/ diarrea/ ayer eché un polvo/ diarrea/ champú/ ¿Cómo se dice "Wonderbra”...?/ gorila (con un perro) en la playa/ hambre/ hicieron trampa en el casino/ morite (voseante)/ orgasmo/ señorita alta y hermosa/ champú/

- $\mathrm{Y}=$ coche/ preservativo/ me apetece un bocata de setas/ pan/ café/ oferta/ cementerio/ guerra/ Oh/

Chino:

- $\mathrm{X}$ = papel de baño/ impotencia/ ¿Quién es el chino más sucio?/ cacao/ divorcio/ minifalda/ orgasmo/ trapecista/ pobre/ cachorrito/ negro/ viuda/ tomado/ suegra/ despeinado/ embarazada/ escándalo sexual/ golpeado/ señorita/ señora/ sinvergüenza/ viuda/ viudo/ precio/ chino sucio/ chica virgen/ abuelo muerto por intoxicación de gambas/ trapecista/

- $\mathrm{Y}=$ náufrago/ gallina viuda/ 99/ pobre/ los tres chinos más pobres/ más alto/ portero de la selección china/ espejo/ chino limpio/ enojado/ descalzo/ nudista/ resorte/

Japonés:

- $\mathrm{X}=$ señorita/ señora/ viejita/ ginecólogo/ barrendero/ ¿Cómo se llama el ministro de agricultura?/ Pedo/ gay (2)/ correrse/ ladrón/ boxeador malo/ diarrea/ secretaria/ los que te quitan las motos/ clítoris/ mujer desvirgada/ eyaculación precoz/ barrendera/ hacer el amor/ minifalda/ bebedor/ indigestión/ bomba atómica/ desnudarse/ luna de miel/ W.C./ doctor/ drogadicto/ hospital/ transporte colectivo/ flaco/

- $\mathrm{Y}=$ encendedor/ piloto/ dentista/ pañuelo/ ¿Cómo se llama el ministro japonés de marina/ Árabe: carpintero/ café amargo/ estoy lleno/ tatuaje/ huerfanito/ político honrado/ músico/

- $\mathrm{X}$ = chica bájate de la moto/ bidé/ te rajo la jeta/ el caballo del jefe/ beso/ codaso (sic) de futbol/ fusilamiento/ adolescente/ escupir/ urinario/ Me he corrido/ diarrea/ tirar de la cadena/ subir en moto/

- $\mathrm{Y}=$ avión/ ascensor/ aparcar/ lluvia/ camión de basura/ terremoto/ agricultor/ perro/

Other languages. Miscellaneous:

Ruso:

- $\mathrm{X}=$ viuda joven/ puta/ suegra/

- $\mathrm{Y}$ = la mujer más delgada/ beso/ ministro de trabajo/ calzoncillos/ ministro ruso de aviación/ frío/ el perro come una dona/ insecto/ conjunto de árboles/ duros inviernos rusos/ Alemán:

- $\mathrm{X}=$ hacerse una paja/ violación/

- $\quad \mathrm{Y}=$ autobús/ trueno/ chaparrón/ galletas con queso/

Portugués:

- $\mathrm{X}=$ tanga (2)/ la raya del pelo/

- $\mathrm{Y}=$ condón/ camión de basura/ calzoncillo/ bigotes/ calvicie/ rodilla/

Francés: 
- $\quad \mathrm{Y}=$ tener muchos hijos/ desnudo/ me equivoqué/ hacer el amor/ no aguanté/

\section{Appendix B.}

English jokes. A selection.

Note: Blatant ones don't exist. All of them are mild.

(a) ¿Cómo se dice beso en inglés? Tu-morrow con el mío (o con mi morrow).

(b) ¿̇...repollo en inglés? Re-chicken.

(c) ¿Cómo se llama el baquero (sic) más guarro? Jonny Me Lavo. (implicit English)

(d) ¿Cómo croan las ranas en el país de los pijos? Rebook. (implicit English).

(e) ... buenos días en Vasco? Egun on. ¿Y buenas noches? Egun off. (textual English)

(f) $\ldots$ perro en inglés? Dog. ¿Y veterinario? Dogtor.

(g) ... UNO en inglés? “'UAN”/ "GUAN” [cuxa, como mi cuñao]

(h) ... en inglés sepelio? Me-mory.

(i) ¿ ¿...en inglés "mi suegra no viene a cenar esta noche"? - Oh yeaaaaaaaaah.

(j) ¿...torero gay en inglés? Ga-torade.

(k) ¿ ¿...talco para caminar? Walkie Talkie.

(l) ¿̇...bañera giratoria en inglés? Tina Turner. 